\title{
Autobiografía, autorretrato y autorreferencia en el Cancionero de Miguel Hernández
}

\author{
José Carlos Rovira \\ Universidad de Alicante \\ ORCID: 0000-0002-4075-1840
}

\begin{abstract}
Desde los conceptos de autobiografía, autorretrato y autorreferencia se realiza la lectura de algunos poemas del Cancionero y romancero de ausencias, no tanto como una perspectiva surgida desde el campo de la teoría literaria, sino insistiendo en los valores que, en la última obra de Miguel Hernández, se entremezclan como dimensión de una existencia en la que sobrevivir era construir una escritura que daba cuenta de sí mismo. Reflejaba así su imagen e incidía metafóricamente en lo que estaban viviendo, como reflejo social y colectivo, aquellos que sufrían las mismas consecuencias de la represión, las cárceles y las condenas a muerte. La realidad provocaba la afirmación de sí mismo a través de recursos que, junto a retóricos, podían testimoniar una nueva dimensión de una poesía y una historia que podemos considerar como la de la derrota en la España de la postguerra civil.
\end{abstract}

Keywords: Autobiografía, autorretrato, autorreferencia, historia, sociedad.

Una cierta debilidad personal (o pereza) ante la teoría literaria me llevó siempre a estar poco interesado en las disquisiciones abstractas que algunos epistemólogos o gnoseólogos nos proponían para la ciencia o el conocimiento de la literatura. Aprendí, quizá por ello, que solo la lectura de los textos, la comprensión de los mismos, su diálogo y aportación en un campo tan amplio como lo que llamamos cultura universal, en la medida en que la fuéramos conociendo, podía sernos de alguna utilidad.

Intento hacer de nuevo una aproximación a varios poemas de Miguel Hernández, como recuerdo de lo que en $1972^{1}$ empecé a realizar. Como han pasado cuarenta y ocho años de aquellas lecturas académicas iniciales -cincuenta y tres de algunos primeros pinitos periodísticos-, espero haber aprendido algo nuevo y, sobre todo, espero saber cómo contarlo.

En un texto de Carlos Bousoño, publicado en 1960, planteó el autor de Teoría de la expresión poética una aproximación que considero muy relevante, a propósito del Cancionero y romancero de ausencias, obra final de Hernández, de la que afirmaba:

I Mi tesis de licenciatura la leí en ese año, y fue transformada en libro sobre el Cancionero (Rovira 1976); mi tesis de doctorado sobre el léxico hernandiano apareció como libro en 1983 (Rovira 1983). Edité el Cancionero y romancero de ausencias cuatro veces, con variaciones importantes en cada edición, desde la primera que anulé al poco tiempo (Hernández 1978, 1985, 1990, 1992). 
Todo poema expresa la vida, pero a veces lo hace de una forma simbólica o indirecta. Miguel Hernández inaugura en este libro, y en otros suyos, una dicción en que la vida queda aludida de un modo relativamente inmediato; en numerosas ocasiones características sentimos el poema incluso como manifestación autobiográfica. En esto Miguel Hernández se adelantó a todos los poetas españoles de su tiempo, y como la estética posterior iba en gran parte a seguir, en diferentes versiones, tal derrotero, el poeta de Orihuela puede ser considerado como uno de los maestros de las venideras generaciones (Bousoño 1960: 33).

Intenté alguna vez entender la dimensión de lo autobiográfico en su desarrollo en la poesía. Recuerdo la lectura, creo que con provecho, de un libro de Michel Beaujour, Miroirs d'encre; rhétorique de l'autoportrait (1980). Este importante crítico distinguió con rigor, a través de sus espejos de tinta, la fórmula del autorretrato literario de la de la autobiografía, lo que sintetizaba en una frase, tras analizar como inevitable la apariencia discontinua y la yuxtaposición anacrónica del autorretrato: «La formule opératoire de l'autoportrait est: "Je ne vous raconterai pas ce que j'ai fait, mais je vais vous dire qui je suis"» (Beaujour 1980: 9) ${ }^{2}$. Decir quién soy a través de mi texto, pero no contar lo que he hecho ni lo que he vivido, es la síntesis del autorretrato, y en Hernández, sobre todo en su final, se unían autobiografía y autorretrato en las propuestas de lectura que hice.

El autobiografismo era, como perspectiva de identificación de una poética a lo largo de poco más de diez años de escritura, el modelo de fusión de la poesía con la vida, que Bousoño, comentando el poema «Antes del odio», valoraba como que el autor «supo alcanzar una alta cima lírica dentro del nuevo género de poesía autobiográfica» (Bousoño 1960: 34).

El autobiografismo del Cancionero, existente sin duda en los poemas que remiten al fin de una guerra y un período carcelario inmediato, que tiene contraseñas de esos dos espacios vitales, presididos también por la muerte de un hijo, el nacimiento de otro, la ausencia de la mujer, de la libertad, la presencia de un odio atenazante, la afirmación del amor como única posibilidad de salvación... va configurando perfiles de una biografía fragmentaria, casi como un diario de cuatro años de la vida de un hombre situado ante un precipicio que determinaba la historia y lo que había vivido, y seguía viviendo de la misma.

En el interior de la construcción autobiográfica, Hernández va creando, además, sucesivas imágenes de sí mismo, fragmentarias, diversas, como diferentes maneras de ir diciéndonos quién es: «Me llamo barro aunque Miguel mellame»(Hernández 1992: 50I), como síntesis y autor representación

2 Fue Hernán Loyola quien en su crítica sobre Neruda me acercó a un artículo de Beaujour (Neruda I98I: I4-I5) y, antes, a los «modos de autorreferencia» en Pablo Neruda (Loyola 1964). 
personal del profundo pesimismo de El rayo que no cesa; «Yo trato que de mí queden / una memoria de sol / y un sonido de valiente» (Hernández I992: 570), dice en «Llamo a la juventud», como síntesis de su imagen en el impulso épico en Viento del pueblo, donde quizá el poema que mejor funde autobiografía y autorretrato sea la «Canción del esposo soldado»... Hernández configura en su obra poética sucesivos autorretratos que podríamos unificar como el pastor, el enamorado, el soldado y el derrotado, pero además introduce un proceso de construcción autorreferencial que defino aquí, sencillamente, como la perspectiva que crea el autor sobre sí mismo a través de un personaje o personajes ficcionales, en el que el autobiografismo se produce también próximo a un espacio vinculado de autorreferencia indirecta, cuando el sujeto poético narra desde una perspectiva distante un tiempo y un lugar en el que se introduce, por ejemplo, desde la tercera persona verbal. Esta es la forma de crear una poética, basada en la autobiografía y la autorreferencia, en el sentido definido por María Teresa Gramuglio de que directa o indirectamente crea imágenes de sí mismo mediante «proyecciones, autoimágenes y también anti-imágenes y contrafiguras de sí mismo» (Gramuglio I988: 3, cit. por Scarano 2017: I38).

En el caso del Cancionero se trata de un procedimiento frecuente que analizaremos en alguno de sus ejemplos principales, pero Hernández utiliza ese modo de autorreferencialidad desde los primeros momentos de su creación, incluso desde Perito en lunas, como libro primero donde la naturaleza es objeto principal de su mirada. En la octava XXXV de la obra, la que se llama «Horno y luna»3, Hernández se plantea el dilema entre la hogaza («la luna de la era [...] dorada [...] alcanzadiza») que está en el horno («el constante estío de ceniza»), y la luna «imposible», la poesía:

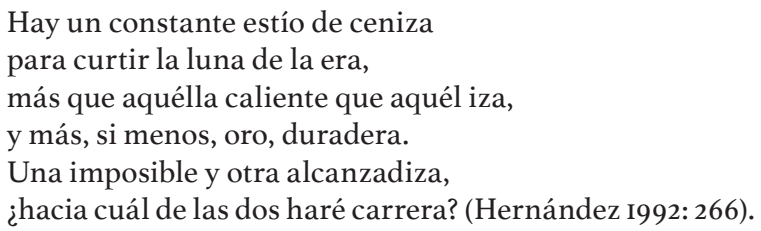

Y se debate entre lo material y su deseo, sobre hacia cuál luna «haré carrera», para resolver en los versos finales hasta el título del libro:

Oh tú, perito en lunas; que yo sepa

qué luna es de mejor sabor y cepa (Hernández 1992: 266).

3 Como sabemos, los títulos de las octavas, que no aparecen en la primera edición, fueron dictados por Miguel Hernández a Miguel Andreu Riera en un ejemplar que este poseía (Cano Ballesta 197I: 6II). 
La autorreferencialidad está marcada aquí por la segunda persona a la que se dirige como vocativo, con la que da, además, título al libro.

\section{Autorreferencialidad diseñada en el marco de la historia}

He dicho ya que, junto al procedimiento autobiográfico, surge la construcción autorreferencial con la que Hernández se sitúa en tercera persona verbal, distanciándose del yo. Es un procedimiento metaliterario que el poeta vive como reflexión no solo sobre su obra, sino sobre el poema y la historia.

El poema inicial al que voy a referirme es «Sepultura de la imaginación»:

Un albañil quería... No le faltaba aliento.

Un albañil quería, piedra tras piedra, muro

tras muro, levantar una imagen al viento

desencadenador en el futuro (Hernández 1992: 757-758).

El albañil es la imagen de sí mismo en un espacio de representación diacrónica, a través del fuerte contenido metafórico y la intensidad de lo narrado como clave histórica. El albañil, alentado, quería levantar, aparte de muros, una imagen dedicada al viento, asociado al futuro y es la memoria, junto al significado del Viento del pueblo, la que aparece recorrida y hasta desencadenada aquí. El edificio que quería construir, por amor, tiene una realidad ascensional, determinada también porque las piedras son plumas y los muros pájaros, movidos por la imaginación. El albañil reía, trabajaba, cantaba, y fueron brotando los muros, que podían tener valor de vuelo, pero la piedra pesa y cobra su densidad por lo que «Aquel hombre labraba su cárcel. / Y en su obra / fueron precipitados él y el viento».

La figura del albañil es una marca autorreferencial, como autorretrato ficticio que, en tercera persona, reconstruye como alegoría la historia del poeta, sepultado con el viento que fue símbolo de la antigua voluntad colectiva en la poesía de la guerra. Pero, al encerrarlo, al hundirlo, lo que se sepulta también es la imaginación. Consideramos que, más allá de todo, es también una reflexión metapoética que establece que lo que está viviendo es el fin de la poesía, porque la realidad sepulta toda ficción creativa. El propio discurso, la propia creación, es cancelada por lo que está sucediendo.

Existe un esbozo del poema y dos manuscritos, uno de los cuales, sin variantes, está incluido en uno de los menús que en homenaje a Miguel Hernández hicieron sus compañeros en su honor el 27 de diciembre de I940, al llegar al Penal de Ocaña. Hernández escribió en cada uno de los trípticos de los amigos una dedicatoria y, en el de Francisco García de la Peña, manuscribió este poema. 
El esbozo tiene un significado diferente al poema final, puesto que es una llamada, en la que insiste por tres veces para pedirle, a manera de estribillo, «albañil, detén el yeso / detén el muro», porque este caerá si se construye, por cansancio también del andamio.

Esta autorreferencialidad, cimentada por una tercera persona que recorre todo el texto y está identificada con el autor, construye otros poemas del último Hernández, como «El pez más viejo del río», un poema breve del que recuerdo siempre, cuando voy a decir algo sobre él, la estremecedora versión de Camarón de la Isla que intensificó la dimensión de ese pez que toma el camino del mar, es decir, el de la muerte. El poema en sus estrofas iniciales dice así:

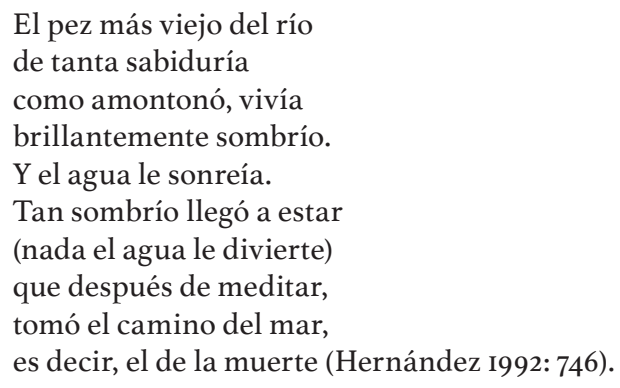

Se publicó en $1946^{4}$, con el título de «A la niña Rosa María», con los últimos versos que decían:
Reíste tú junto al río
niña solar. Ese día
el pez más viejo del río
se quitó el aire sombrío.
Y el agua te sonreía (Hernández 1992: 747).

Creo ahora, después de editar el poema varias veces, que es la versión primera la que determina a la «niña solar», porque en dos cartas me narró la escritura del poema un compañero de varias cárceles, Antonio Buero Vallejo, aunque no estuviera con Hernández en el momento que lo escribió. Decía Buero que, al llegar él a Ocaña cuando Hernández ya había sido trasladado a Alicante en junio de 194I, le contaron que «un compañero de prisión desconocido cavilaba, mirando el retrato de su hija, en qué podía mandarle o decirle con motivo de su santo o su cumpleaños. Le explicó a Miguel lo que

4 En Hernández (1946). Estuvo entre las primeras ediciones, si no la primera, de la obra carcelaria, donde aparecen, además, las «Nanas de la cebolla» (tituladas «Nanas a mi niña»), «Sepultura de la imaginación», «Ascensión de la escoba», etc. 
le sucedía y Miguel vio la foto. Se la pidió por un rato, se volvió a su petate y tiempo después devolvió la foto con esa poesía para la hija de su compañero». De esto me informó en una carta de 30 de marzo de 1978 , pero el 17 de abril de 1985, en otra carta más amplia, precisaba sobre otros poemas que yo había editado, y sobre este de nuevo:

En sus dos libros "El pez más viejo del río" se considera dirigido a un niño; probablemente a su hijo. Y en el fondo esto es, seguramente, muy exacto. Ahora bien [reitera aquí la historia de Ocaña ya contada y concluye] que el recuerdo de su propio hijo estuviese al fondo es seguro; y es posible que tan lógica suposición sea la que haya transformado la niña en "niño".

Lo que me parece seguro es que el poema tuvo dos destinatarios, la hija de aquel compañero de cárcel y su propio hijo, pues desde la prisión de Ocaña le hizo llegar un dibujo a Josefina -no podemos asegurar que con el texto- que es este que edito, donde el pez más viejo del río, o el sol, construyen referentes materiales, es decir, un autorreferente y una imagen solar de la niña o el niño al que dirige el poema, para que el agua le sonría de nuevo:

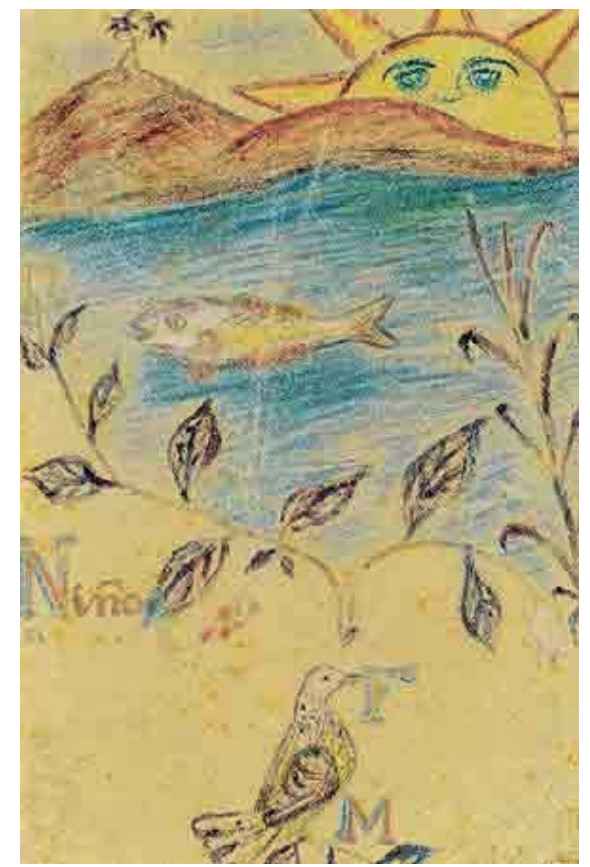

Fig. I: Dibujo de Hernández sobre «El pez más viejo del río», enero de I94I. 
Hay otros poemas autorreferenciales como «Después del amor»o «Vuelo», junto a poemas indiciariamente autobiográficos como las «Nanas de la cebolla», «Antes del odio» 0 «Eterna sombra».

\section{El signo de los enamorados perseguidos}

Hay una construcción, a través de la tercera persona verbal en plural, que genera uno de los signos principales de la obra, el de los amantes perseguidos. Me refiero a uno de los poemas que considero más importantes de la obra, el «Vals de los enamorados y unidos hasta siempre», cuyas palabras, a través de su aparente sencillez se convierten en una lección intertextual y metatextual de literatura. Recuerdo el «Vals»:

No salieron jamás

del vergel del abrazo.

Y ante el rojo rosal

de los besos rodaron.

Huracanes quisieron

con rencor separarlos.

Y las hachas tajantes

y los rígidos rayos.

Aumentaron la tierra

de las pálidas manos.

Precipicios midieron

por el viento impulsados

entre bocas deshechas.

Recorrieron naufragios

cada vez más profundos

en sus cuerpos, sus brazos.

Perseguidos, hundidos

por un gran desamparo

de recuerdos y lunas,

de noviembres y marzos,

aventados se vieron

como polvo liviano:

aventados se vieron,

pero siempre abrazados (Hernández 1992: 688). 
Hernández lo escribió a los 29 años en el álbum de un amigo, a fines del 39, en la prisión Conde de Toreno de Madrid. Hay una versión anterior en el cuaderno de Cancionero y romancero de ausencias ${ }^{5}$.

Hay sabiduría poética en el texto, juegos y contraseñas que dotan al poema de eficacia. Los acentos ternarios en la sílaba tercera y sexta, casi permanentes, construyen un decurso rítmico que hace del poema un «Vals», que temáticamente se abre con un círculo de amor en el que danzan los enamorados, ruedan efectivamente en el «vergel del abrazo» $\mathrm{y}$ «ante el rojo rosal». Ya tenemos el jardín de amor de la tradición literaria. Si repasamos la estructura sintáctica de la primera estrofa es casi un quiasmo, en una circularidad gramatical que refuerza de nuevo la denominación de «Vals».

Algo quiere destruir el círculo de amor: «huracanes» que son inversión semántica, como en otros términos clave del período, del viento positivo construido antes como «viento del pueblo»: ahora el viento de final de la guerra civil y de la cárcel es en otros poemas «viento de encono», «viento ceniciento», «viento que no amó». Intentan destruir el círculo, además, «hachas tajantes» $\mathrm{y}$ «rígidos rayos» que, aparte de la inversión semántica de «rayos», soporta una acumulación fonética de palatales y vibrantes que connota violencia (recordemos en la famosa «Elegía a Ramón Sijé»: «en mis manos levanto una tormenta / de piedras, rayos y hachas estridentes / sedienta de catástrofes y hambrienta»).

El poema sigue (omito el comentario pormenorizado de «tierra», «manos», «bocas», «naufragios» que tienen una variación contextual aquí en relación a usos frecuentes anteriores) con el hundimiento de los enamorados hacia lo que llamé hace años «lo descendido» (en oposición a la construcción positiva de «lo elevado» que estructura el Cancionero junto a la oposición Luz/ Sombra, lección segura de San Juan de la Cruz), para concluir con un evidente recuerdo del «polvo enamorado» quevediano, en el que los enamorados de Hernández son lanzados al aire, convertidos en polvo, pero abrazados (recordaba siempre que también era adversativa la frase final del famoso soneto de Quevedo que concluye con el «polvo serán mas polvo enamorado»).

El poeta de raíz popular, con sus 29 años, había adquirido ya una sabiduría constructiva y metafórica que tenía como base su formación continuada en la tradición, en los grandes modelos de la misma: San Juan, Quevedo (como antes Góngora, Calderón o Lope) le acompañaban en su decir, pero reactualizando el modelo mediante una escritura propia que no ha dejado de interesarme y con frecuencia -en actitud menos profesoral y académica- de emocionarme.

5 Hay una edición facsimilar del Cuaderno del Cancionero y Romancero de ausencias, que es la base algo ordenada para fijar la edición del texto, que nunca será definitiva al no haberla concluido ni decidido el poeta (Hernández 1985). Aparte hay dos conjuntos más de manuscritos que se unen al bloque principal del Cuaderno (que a veces solo contiene títulos con puntos suspensivos) como analizo en las ediciones Hernández 1990 y 1992. 
Además, hubo otras cosas siempre en la lectura de este poema. Fragmentos de memoria que me sirvieron para entender lo que vivía: los enamorados de Hernández se me asociaron muy pronto con otra lectura juvenil, con su afirmación de la vida y el amor a pesar de la tragedia. Recuerdo la sorpresa también de las Cronache di poveri amanti de Vasco Pratolini. Cuando leí este poema de Hernández, cuando leí el Cancionero (que luego intermitentemente me dediqué a reconstruir en varios intentos) no podía dejar de evocar un párrafo que identificaba narrativamente el sentido global como afirmación de la vida. Recordaba al personaje Maciste recorriendo las calles de Florencia en una motocicleta para avisar a los antifascistas que iban a ser detenidos y, tras el asesinato del personaje en el mismo episodio, una frase abre la tercera parte del libro: «Poi fu inverno veramente, passarono dei mesi, e per scampare al terrore che incuteva idee di morte, ciascuno guardò piú attentamente alla vita» (Pratolini 1974: 333). La afirmación de la vida contra el terror une los dos significados globales que evoco.

Lo más importante es quizá que, al aludir a la propia identidad como autorreferencia, esta se hace símbolo, a través de la tercera persona verbal -los enamorados, él, ella- de la identidad social de los que estaban viviendo las mismas circunstancias, los derrotados.

Además, en el Cuaderno del Cancionero, los amantes de Hernández adquieren en los poemas más próximos al «Vals», el anterior y posterior, una dimensión claramente autobiográfica a través de la primera persona plural en el primero: «¿Qué quiere el viento de encono?» (Hernández I992: 687), donde el poeta nos habla también de un viento que intenta derribar y arrastrar a los amantes; estos se alejan, pero el viento «cada vez más enconado» busca causar más daño, quiere «separarlos». La referencia es ahora directamente personal y amplía su significado gradualmente, mediante la acción verbal: «Derribarnos [...] arrastrarnos» y, cuando las dos sangres se alejan, quiere «separarnos» (Hernández 1992: 688).

El posesivo marca la identificación absoluta del empoderamiento que «el viento que no amó» va a hacer del hogar familiar, en el poema que sigue al «Vals»:

\author{
Un viento ceniciento \\ clama en la habitación \\ donde clamaba ella \\ ciñéndose a mi voz. \\ Cámara solitaria, \\ con el herido son \\ del ceniciento viento \\ clamante alrededor [...] (Hernández I992: 689).
}


La soledad determina el espacio de la nueva situación, creando en el sonido del viento la sustitución del antiguo clamor de la amada.

\section{¿Metaliteratura en el cuaderno y en los manuscritos del Can- cionero?}

Creo que la voluntad de escritura que Hernández despliega en sus papeles finales tiene, sobre todo, un sentido de supervivencia, no solo personal, sino familiar. Está muy narrado que un día consigue hacerle llegar a su mujer, Josefina Manresa, un conjunto de manuscritos elaborados durante el final de la guerra y la primera etapa carcelaria, y le dice en una nota desde la cárcel que fue el Seminario de Orihuela, a fines de 1939: «Ya trabajo algo. Guarda bien estos originales que os envío donde están los otros. No se pierdan, que no tengo copia. Si tengo cinco o seis libros escritos cuando salga de aquí tenemos pan seguro cuando se publiquen, si antes no nos hemos muerto de hambre» (Manresa 1980: 22). Y otras veces: «Guarda estos papeles, que son mi trabajo de dos años y vuestro pan de mañana» ${ }^{6}$. En el segundo período de cárcel, escribe detrás del autógrafo de «Muerte nupcial» que le hace llegar a Josefina con otros poemas: «Guarda bien estos originales que te envío, Josefina, en la libreta que traje de Madrid con tu retrato y el del niño» (Legado: 35I273. pdf).
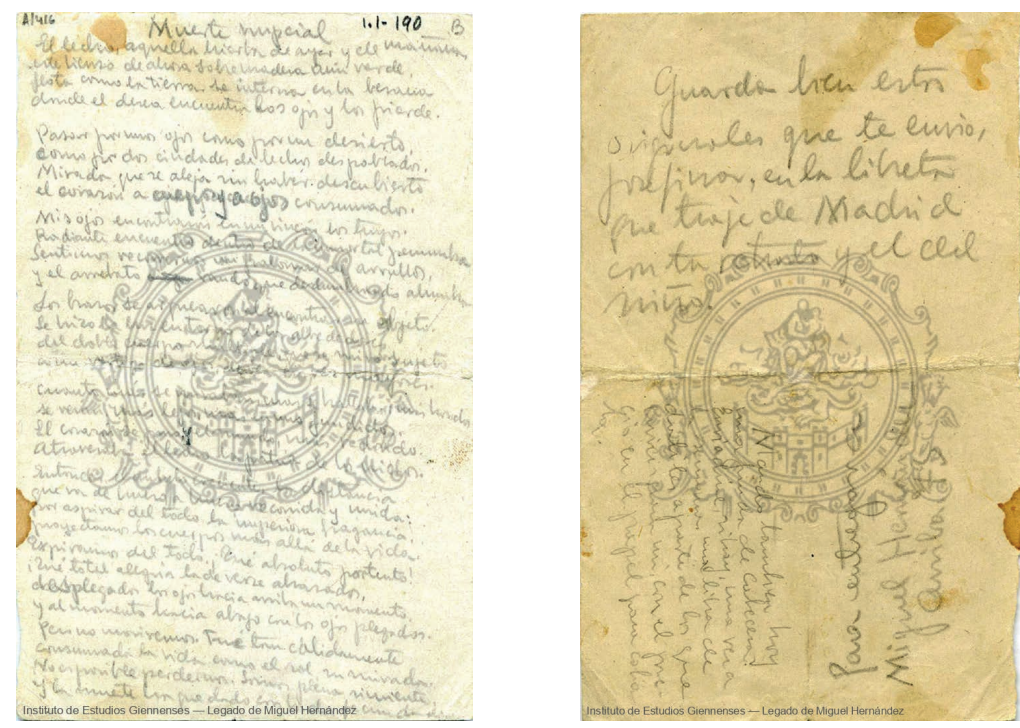

Fig. 2 y 3: «Muerte nupcial» y nota autógrafa (Legado: 35I273. pdf).

6 Ha sido muy citada esta frase en todas las biografías. La destaca, por ejemplo, Leopoldo de Luis (2005: 587). 
No creo que podamos hablar tanto de metapoesía como de una escritura metasocial y metahistórica para seguir con el juego crítico del prefijo insistente.

Hernández tuvo preocupación - difícil, ingenua a veces, pero eficaz en cualquier caso- por definir una poética. Y lo hizo desde el principio, cuando escribía por ejemplo «Mi concepto del poema», donde lo definía, en diálogo con un lector imaginario, como «una bella mentira fingida. Una verdad insinuada [...]», en un texto probablemente de 1933. Ocho años después, por encima de cualquier determinación de una poética, las palabras adquirían el carácter de una defensa frente a la realidad y la historia vividas, protegiéndose de la misma como un albañil que construía los muros que lo iban a sepultar junto a la imaginación, o como el pez más viejo del río, o más aún como aquellos enamorados que a pesar del terror aparecían unidos hasta siempre: ¿autobiografía? ¿autorretrato? ¿autorreferencia? Realmente, no lo sé. Posiblemente, lo determinan los tres procedimientos de identificación de sí mismo en un momento trágico en el que había que seguir, sobre todo, escribiendo y sobreviviendo.

\section{Bibliografía}

Beaujour, Michel, Miroirs d'encre; rhétorique de l'autoportrait, París, Seuil, 1980. Bousoño, Carlos, «Notas de un poema de M.H.: "Antes del odio"», Cuadernos de Ágora, 49-50, Madrid, 1960, pp. 33-34.

Cano Ballesta, Juan, La poesía de Miguel Hernández, Madrid, Gredos, $2^{\text {a }}$ edición, 1971.

Gramuglio, María Teresa, «La construcción de la imagen», Revista de Literatura, 4, noviembre, 1988, pp. 3-16.

Hernández, Miguel, Poemas, Halcón. Revista de poesía, 9, agosto de 1946.

-. Cancionero y romancero de ausencias, ed. José Carlos Rovira, Barcelona, Lumen/El Bardo, 1978.

-. Cuaderno del Cancionero y romancero de ausencias, ed. facsímil, introducción, transcripción y notas de José Carlos Rovira, Alicante, Instituto de Estudios Juan Gil-Albert, 1985.

- Cancionero y romancero de ausencias, ed. José Carlos Rovira, Madrid, Espasa-Calpe/Austral, 1990.

-. Obra Completa, ed. Agustín Sánchez Vidal y José Carlos Rovira con la colaboración de Carmen Alemany Bay, Madrid, Espasa Calpe, Vols. I (poesía) y II (Teatro, Prosas, Correspondencia), 1992.

Legado M. Hernández: https://www.dipujaen.es/miguelhernandez [II.02.202I]. Loyola, Hernán, Los modos de autorreferencia en la poesía de Pablo Neruda, Santiago de Chile, Aurora, 1964. 
Luis, Leopoldo de, «Correo para la muerte», en Presente y futuro de Miguel Hernández, eds. Aitor Luis Larrabide, Juan José Sánchez Balaguer y Francisco Ramírez, Orihuela, Fundación cultural Miguel Hernández, 1985, pp. 585-697.

Manresa, Josefina, Recuerdos de la viuda de Miguel Hernández, Madrid, Ediciones de la Torre, 1980.

Neruda, Pablo, Antología poética, ed. Hernán Loyola, Madrid, Alianza Editorial, 198I, 2 Vols.

Pratolini, Vasco, Cronache di poveri amanti, Milano, Oscar Mondadori, 1974.

Rovira, José Carlos, Cancionero y romancero de ausencias de Miguel Hernández. Aproximación crítica, Alicante, Instituto de Estudios Alicantinos, 1976.

- Léxico y creación poética en Miguel Hernández. Estudios del uso de un vocabulario, Alicante, Universidad/Caja de Ahorros Provincial, 1983.

Scarano, Laura, «Escribo que escribo: De la metapoesía a las autopoéticas», Tropelías. Revista de Teoría de la literatura y Literatura Comparada, 2, 20I7, pp. 133-152. 